\title{
Toward convergence in the St. Petersburg hotel industry through the lens of institutional theory ${ }^{*}$
}

\author{
Päivi Karhunen ${ }^{* *}$
}

The article assesses the power of institutional organization theory in explaining enterprise adaptation in post-socialism. Empirical analysis of the hotel sector in St. Petersburg, Russia, shows that industry-level isomorphic forces are not at work during economic transition. Combined with market imperfections, this results in intra-industry strategic diversity. The underlying logic however changes as the transition proceeds. During the transition, diversity is based on local versus foreign management and during the post-transition on the legitimacy of operations. The majority of hotels start operating according to shared norms and practices, whereas the lack of coercive pressures from the state still allows some hotels to operate in the shadow and ignore institutional norms.

Der Artikel untersucht die Möglichkeiten der institutionellen Organisationstheorie zur Erklärung der Unternehmensanpassung im PostSozialismus. Empirische Analysen des Hotelsektors in St. Petersburg, zeigen, dass isomorphe Kräfte auf Industrieniveau während des ökonomischen Überganges nicht funktionieren. Kombiniert mit Marktunvollkommenheiten, führt dies zu intra-industriellen strategischer Vielfalt. Die zugrunde liegende Logik ändert sich jedoch mit fortschreitender Transformation. Während der Transformation basiert die Verschiedenartigkeit auf Gegensätzlichkeit von lokalem zu ausländischem Management, während der Post-Transformation auf der Legitimität der Geschäftstätigkeit. Die Mehrheit der Hotels beginnt, sich an gemeinsamen Normen und Praktiken zu orientieren, wobei der mangelnde Druck von Seiten des Staates noch einige Hotels erlaubt, halblegal zu agieren und institutionelle Normen zu ignorieren.

Key words: Hotel industry, transition economies, Russia, institutional isonorphism, organizational field

* Manuscript received: 30.08.07, accepted: 07.04.08 (1 revision)

** Päivi Karhunen, Dr., Research Team for Russia and the Commonwealth of Independent States, Helsinki School of Economics' Centre for markets in Tansition, Finland. Main research areas: Institutional change in transition economics, and its implications for international business strategies. Corresponding address: paivi.karhunen@hse.fi. 


\section{Introduction}

Enterprise adaptation to economic transition has generated a substantial number of studies in management research. The strategies of foreign entrants and the restructuring of local incumbents have been the focus of research, and questions related to new business creation have started to receive attention. The theoretical perspectives applied in existing research have varied, but due to the emphasized relationship between institutions and business strategies in transition economies, institutional theory has become a new dominant approach (Hoskisson et al. 2000; Meyer/Peng 2005; Wright et al. 2005).

Recent research has identified a number of institutionally derived forces (Meyer/Peng 2005) that affect business strategies in a post-socialist environment through transaction costs (Meyer 2001) or relational networks (Peng/Heath 1996). Such research has aimed at advancing institutional theory by building on the evidence of post-socialist transition as a specific empirical context. For example, it has been shown that the institutional framework in transition economies constrains foreign entry strategies in terms of choice of entry mode (Salmi 1995; Brouthers/Bamossy 1997; Peng 2000; Meyer/Estrin 2001; Meyer 2001; Karhunen 2002; Meyer/Nguyen 2005) and location choice (Bevan et al. 2004).

Another body of research has investigated institutionally derived phenomena, such as the management culture in local enterprises, without explicitly referring to institutional scholars in their theoretical framework. For example, differences between Western and Russian management cultures (Puffer et al. 1996; Ralston et al. 1997) and their implications for managerial practices regarding, for example, knowledge sharing (Michailova/Husted 2003; Hutchings/Michailova 2004), learning (Child/Markóczy 1993) and the implementation of organizational change (Michailova 2000) have been analyzed.

Characteristically, existing studies building on institutional theory have often focused on one group of enterprises (foreign entrants, local incumbents, or new start-ups) at a time. Treating these enterprise groups separately has been justified, as in the early years of economic transition, the challenges faced by each of them varied greatly (Peng 2003). Foreign entrants had to cope with a novel host environment, formerly state-owned enterprises had to restructure their operations to meet market conditions, and new businesses had to cope with institutional imperfections for new business creation. However, those studies that have investigated the behaviour of the three groups of enterprises in parallel have shown that the link between enterprise type and business strategy is not straightforward. For example, foreign entrants may apply practices deriving from the socialist past, whereas there are former state enterprises that have rapidly abandoned them (Kosonen 2004). On the other hand, it has been proposed that the institutional pressures faced by the three types of enterprises converge as the transition proceeds, which narrows the gap between their 
strategic behaviours (Peng 2003). Now, as the macro-level transition has been officially completed in most of the transition economies, including the Russian Federation, it is time to compare the strategic behaviours of these groups of enterprises in more detail.

In addition, I argue that existing management research on transition economies has not exploited the analytical opportunities provided by the institutional approach in full. Most of the existing research has linked firm strategies directly to the macro-level institutional context, without depicting sector- or industrylevel processes. Such an intermediate unit of analysis is important to take into account, as macro-level institutional forces, such as federal and state regulations, are often mediated to organizations by field-level structures and processes (Scott 1998:130). This has been recently demonstrated in the transition context by Puffer and McCarthy (2007), who showed that the institutional change in Russia has resulted in different types of capitalism. Developing the concepts of institutional pull and institutional push (i.e., institution-building originating from companies versus the state, respectively) they identified inter-industry differences in the nature of capitalism, ranging from market capitalism in the consumer sector to state-led capitalism in natural-resource based sectors (ibid).

This article aims at contributing to filling the gaps in the existing literature by applying institutional organization theory to depict enterprise adaptation to postsocialism at the industry level. This is done by empirically analyzing the hotel industry in the Russian city of St. Petersburg.

The article is structured as follows. First, the theoretical background for the study is discussed. Then, data and methodology applied in the empirical analysis are presented. This is followed by the empirical description, which is divided into two sections; the transition period (1991-1998 financial crisis in Russia) and the post-transition period (1998 crisis-2005). The organizational practices of foreign and Russian managed hotel enterprises are analyzed and compared within each section. Finally, conclusions and suggestions for further research are discussed.

\section{Theoretical background}

This article builds on the neo-institutional organization theory, which provides analytical tools for examining enterprise behaviour at the industry level. A key concept in neo-institutional organizational analysis is organizational field, defined as "those organizations that, in aggregate, constitute a recognized area of institutional life: key suppliers, resource and product consumers, regulatory agencies and other organizations that produce similar services or products" (DiMaggio/Powell 1983). In this article, the St. Petersburg hotel industry is viewed as an organizational field, consisting of hotel enterprises, their suppliers and customers, and related institutional actors such as the city government. 
The neo-institutional organization theory assumes that organizations in a field become increasingly homogeneous over time, as they seek legitimacy within their environment. In other words, the institutional context provides organizations with field-specific "templates of organizing" (DiMaggio/Powell 1991:27), which are transmitted by the state, professional associations, regulatory agencies and leading organizations (Tolbert 1985; Greenwood/Hinings 1996).

The process of field-level strategic and structural homogenization is referred to as institutional isomorphism, which occurs through three mechanisms (DiMaggio/Powell 1983). Coercive isomorphism results from institutional pressures exerted on organizations by other, [often state] organizations upon which they are dependent, and by cultural expectations in the society (DiMaggio/Powell 1983). For example, the government may introduce new legislation, which organizations have to comply with. Mimetic isomorphism implies that organizations tend to model themselves after other organizations that they consider to be more legitimate or successful. This occurs indirectly through employee transfer or turnover, or explicitly by organizations such as consulting firms or industry trade associations (DiMaggio/Powell 1983). Finally, normative isomorphism stems from professionalization - the collective struggle of members of an occupation to define the conditions and methods of their work (Larson 1977:49-52). Universities and professional training institutions are an important source of professionalization; another is the growth and elaboration of professional networks that span organizations and across which new models diffuse rapidly (DiMaggio/Powell 1983).

In transition economies, where the institutional context itself is in flux, I argue that the above-mentioned mechanisms of isomorphic change are not necessarily at work. In a situation where formal regulation and the mechanisms to control its enforcement need to be reformed, coercive isomorphic pressures may be expected to be weak until the new institutional framework is functioning properly. In addition, the mechanisms of diffusion of organizational models seem to need well-established field-level institutions, such as industry associations. This would predict weak mimetic isomorphic pressures in transition economies where all structures of the economy are undergoing change. Finally, I argue that professionalization is not likely to take place when managers have different cognitive bases, moulded by different education systems ranging from the ideology-flavoured Soviet party schools to Western business schools. Hence, normative isomorphic pressures are likely to be weak as well.

The weakness of the isomorphic pressures implies that the institutional context does not provide enterprises with well-established templates of organizing. As a consequence, local incumbents tend to resort to their old practices, however irrelevant they may be in the new situation (Newman 2000). The heavier the 
"institutional baggage" of the organization, the more difficult it is to unlearn old practices (Roth/Kostova, 2003). In contrast, foreign enterprises are likely to import their established practices into the new context. Hence, it can be argued that during economic transition intra-field diversity of organizational practices can be expected. As market economy institutions gain strength, new shared templates of organizing would evolve. This article empirically examines whether such change from diversity to homogeneity takes place as the transition proceeds. This is done by comparing the behaviour of old Soviet-era hotels, new Russian-managed start-ups and foreign-managed hotels in St. Petersburg from the transition (1991-1998 crisis) to the post-transition (1998 crisis-2005) period.

The theoretical framework of the article is operationalised into a conceptual model, which is presented in Figure 1.

The model summarizes the key assumptions of institutional theory about the interplay of the institutional context and enterprise behaviour during economic transition. First, it proposes that coercive, mimetic and normative institutional isomorphic pressures towards homogeneity are weak during transition and provide organizations with no templates of organizing. Consequently, old Soviet hotels would resort to the templates of the socialist past, and foreign-managed hotels apply templates of the global hotel industry, rooted in developed market economies. New start-ups, which have lighter "institutional baggage" than old Soviet hotels, would adopt elements of both templates. Hence, there would be diversity in the practices of the three types of hotels. Second, the model suggests that as the transition proceeds and the market economy gains a stronger foothold, institutional isomorphic pressures would gain strength and result in new templates of organizing characteristic of the post-transition period. Such templates would combine elements from the socialist past with global hotel industry practices and new practices developed during the transition era. This would result in the convergence of practices between the three types of hotels.

To empirically approach the templates of organizing, I examine the structure and practices of the hotels as follows. At the structural level, I discuss the ownership structure and operation mode of hotels. Practices of hotels are analyzed with respect to their relations with other members of the production chain (i.e. suppliers and customers) and through their HRM strategy. In addition, I investigate the practices that hotel enterprises apply in their relations with the public sector.

Before going into the empirical description, the following section describes the data and methodology applied in the empirical analysis of the article.

1 Defined as "The strength, ingrainment, and pervasiveness of the institutional arrangements that existed prior to the radical change" (Roth/Kostova, 2003: 316). 
Figure 1. Conceptual model of the article

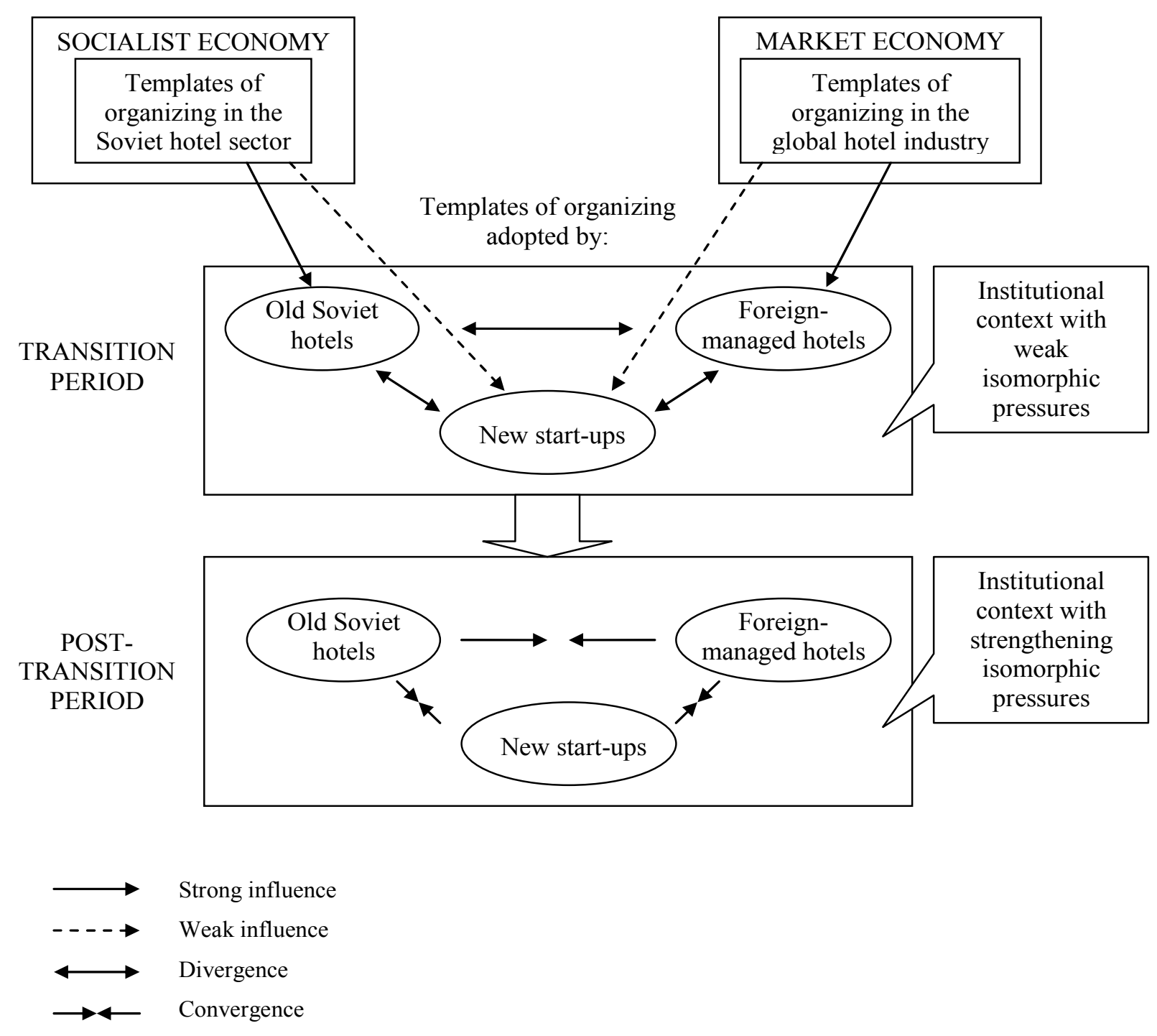

\section{Data und methodology}

The empirical part of the article builds on a qualitative case study, describing changes in enterprise structure and practices in the St Petersburg hotel sector from the socialist period until 2005. The primary empirical data of the study consists of 27 thematic interviews, conducted with the top management of St Petersburg-based hotels between 1999 and 2006. The interviewees represented foreign management companies ( 7 interviews), hotels dating from the Soviet period (10 interviews), and Russian-managed hotels established after the collapse of the Soviet Union (10 interviews). The hotels have different profiles regarding, for example, size (from mini-hotels to former Soviet "giants"), level of service (from budget to 5-star hotels), and the level of standardization of the business concept (independent versus chain hotels). 
The interviews were conducted according to an interview guide with open-ended thematic questions. The aim of the interviews was to gain rich descriptions of the hotel industry's development over time from two viewpoints. First, different functions of each hotel's "production process", such as human resource management, supply, and marketing were touched upon. Second, the hotel managers' views of the institutional context, such as the relationship between their hotels and the city government, were addressed.

In addition to interview data, a key data source was the collection of newspaper and journal articles from the Russian press between 1992 and 2005. These articles describe the development of the institutional context in the hotel industry in Russia in general and in St. Petersburg in particular. These data were utilized to triangulate and support the interview data. Finally, the two main data sources were complemented by reports from consulting companies and other industry observers.

In the empirical analysis, a temporal bracketing strategy was applied (Langley 1999) by separating the interview data into two successive periods (transition and post-transition) based on a discontinuity at their boundary (the 1998 financial crisis in Russia). The development of the institutional context and its implications for hotel enterprises' structures and practices were then studied within each phase. After retrieving all relevant information from the interviews, the narrative was complemented by additional information from the documentary data sources and "bracketed" into the two time periods.

\section{The empirical context: An overview of the St. Petersburg hotel industry}

In the Soviet era, the hotel sector in St. Petersburg (then Leningrad) was administered through state tourism organizations. These were the state enterprise for international tourism 'Intourist', the bureau of international youth tourism 'Sputnik', and the Central Soviet for Tourism and Excursions, which organized domestic tourism (Gavrilov 1998:210). Each organization had its own hotel stock. In addition, there were municipal hotels and so-called vedomstvennye (corporate) hotels associated with state enterprises and political organizations (Kvartal'nov 1999).

When the Soviet Union collapsed, the ownership of the hotel properties was rearranged. Hotels previously managed by ministries and state enterprises either remained affiliated with these organizations or were privatized with their management and employees as the new shareholders. Most hotels, however, including those of Intourist, were allocated to local and regional authorities (Gudbergsen 1996). As a result, the local governments became major players in the industry, especially in Moscow and St. Petersburg.

The contemporary St. Petersburg hotel industry consists of several types of hotels, ranging from former state-owned hotels to high-level foreign-managed 
properties and mini-hotels. The majority of the hotel stock has been constructed in the Soviet period, in particular in the 1960s and the 1970s.

Figure 2. Transition - period of divergence

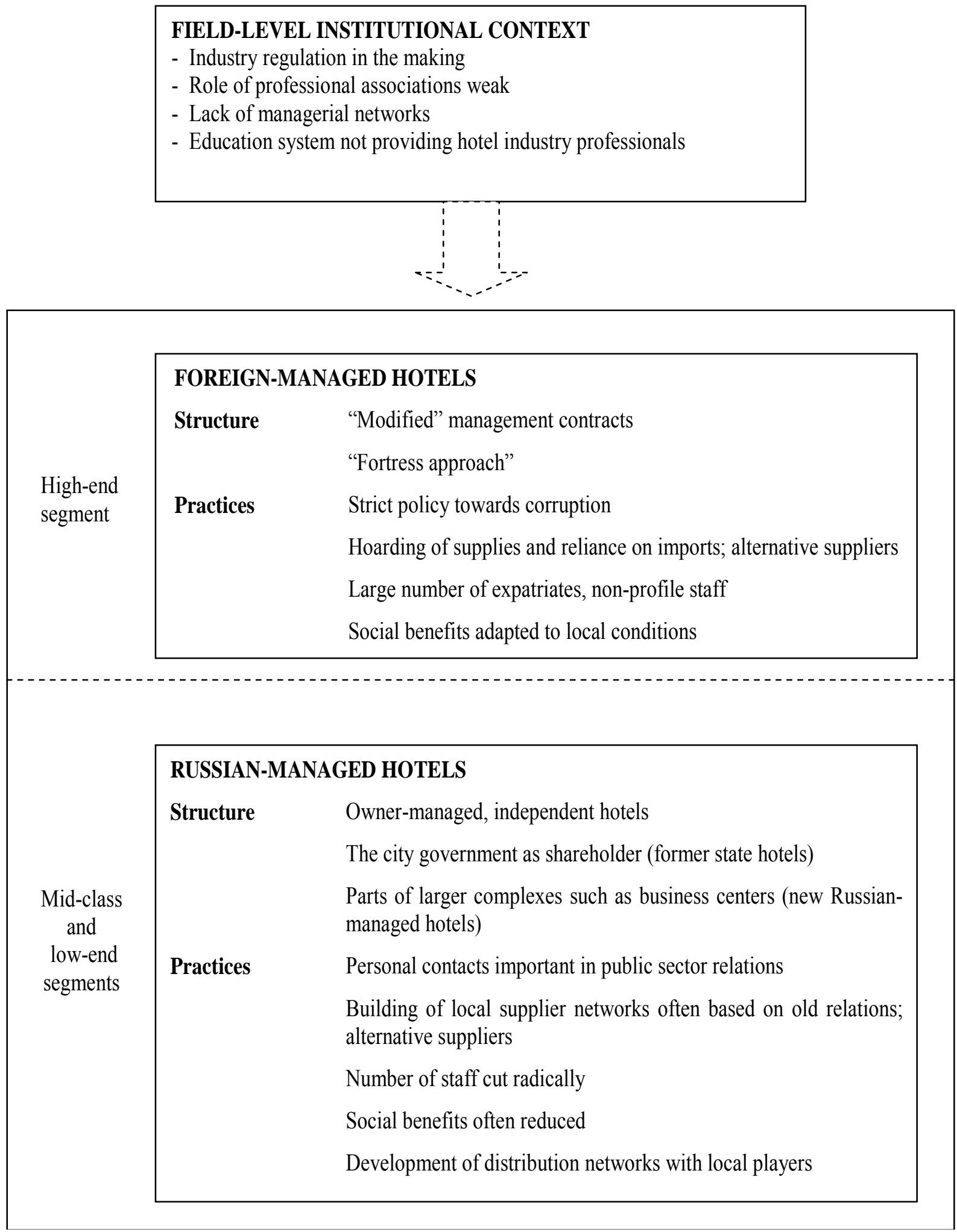


The construction of new hotels picked up only in the first half of the 2000s. In addition, the city's $300^{\text {th }}$ anniversary in 2003 stimulated the opening of minihotels, which were often renovated from Soviet-time communal apartments in the city centre. Russian real estate developers have also increasingly started to invest in hotel construction. Some of these hotels are joint projects with international management companies.

After this brief overview of the empirical context, I now move on to analyzing the organizational practices in the St. Petersburg hotel sector more in detail. This is done by describing the field-level institutional context and enterprise strategies in the two time periods, transition (1991-1998 crisis) and posttransition (1998 crisis - 2005).

\section{Transition period - divergence between "us and them"}

This section illustrates the St. Petersburg hotel industry during the transition period, starting from the collapse of the Soviet Union in 1991 and ending with the 1998 financial crisis in Russia. Figure 2 summarizes the main aspects of this period.

The figure illustrates how the institutional context during the transition provided weak pressures toward homogeneity, resulting in strategic and structural divergence between foreign and Russian-managed hotels. As a result, the hotel market had foreign-managed properties in the high-end segment and Russianmanaged ones in the mid- and low-end segments. The majority of the properties were old Soviet hotels, as new-start ups were still few.

\section{Institutional environment during transition: Field-level institutions in the making}

The institutional context faced by hotel enterprises during the transition was in flux, and because of that all three types of pressures for homogeneity (coercive, mimetic and normative) were weak. The coercive pressures exerted by the state weakened due to the dismantling of the state tourism organizations. At the same time, industry regulations meeting market conditions needed to be created. The legislation concerning the hotel industry was ambiguous. For example, licensing of hotel operations was required only in Moscow. Moreover, although a national rating system to control the quality of hotels was introduced already in 1994, certification was voluntary and any organization registered in the state standardization committee could grant stars. This eroded the credibility of the system.

The dissolution of the state tourism organizations with their coordination mechanisms and standards left a vacuum in the field as regards mimetic isomorphic forces, too. Industry associations started to emerge, but their influence in disseminating practices was limited. In addition, the presence of 
hotel management chains in the sector was limited to a handful of foreignmanaged properties. On the one hand, there were no local chains that Russianmanaged hotels could have joined and on the other hand their quality was not sufficient to become members of international chains. In addition, the attitudes of hotel owners were against giving up control to an outside hotel management company. Consequently, Russian-managed hotels largely operated each according to their own principles. Mimetic isomorphism leading to the dissemination of practices was also hindered by limited personnel transfer between hotels. On the one hand, foreign hotels did not want to hire personnel with experience from the Soviet service culture, and on the other hand, Russian hotels needed to rather reduce staff than hire new people.

Furthermore, normative isomorphic pressures were weakened by the low level of professionalization. Both key sources of professionalization, managerial networks and a shared educational base, were limited. Managerial networking took place mainly among foreign hoteliers, whereas there was little interaction among managers of former Soviet hotels. The Soviet practice of information hoarding was prominent, as hotels did not want to share information for fear of revealing business secrets. Moreover, the educational base of hotel managers and staff was diverse. As there had been little specialized training for hotel managers in the Soviet Union, Russian hotel managers had different backgrounds. In addition, as the training institutes of state tourism structures were closed, the system of education for hotel industry professionals had to be created anew. In part, state-owned universities introduced degree programs for tourism, and new professional institutes were opened. However, the Soviet legacy was present in the curricula of these institutions, as their emphasis was on economic and technical subjects (Karpova 2003). As a result, universities and training institutes were not able to provide qualified personnel and management for the city's hotels.

All in all, these factors resulted in weak pressures for industry-level homogenization of organizational practices. In addition, hotel enterprises had to cope with market imperfections resulting from the systemic change. Here, foreign enterprises resorted to their global resource base, whereas Russianmanaged hotels needed to build local linkages. This is illustrated in the following sections.

\section{Organizational practices of hotel enterprises during transition}

As regards structure, both old Soviet and foreign-managed hotels had to adapt their existing templates of organizing to the transitional context. As the state tourism organizations were dissolved, hotel directors had to take the responsibility for strategic planning and decision-making. Consequently, hotels introduced functions that had been performed by state tourism structures and opened corresponding departments. This included sales and marketing, and the 
provision of support services such as transportation. However, the operation mode as such did not change, as former state hotels continued to be ownermanaged. In addition, private ownership was rare as the majority of former state hotels were owned by the city government. The city government was also heavily involved in foreign-managed operations. Basically the only option for foreign hotel management companies to enter the St. Petersburg market was to form a joint venture with the city government. In addition to requiring an investment in the property from the foreign partner, the city government also wanted to participate in the management resulting in "modified" management contracts.

New start-ups, which were still rare, were often parts of larger complexes such as business centres, which started to mushroom in the city. The demand for office space and other business infrastructure benefited also the old Soviet hotels, which compensated for the decrease in demand by transforming a part of their room capacity into office space. Furthermore, with a lack of quality apartments for rent, businesspeople even lived in hotels on a long-term basis. In high-class foreign-managed hotels this "fortress approach" included also a more extensive in-house supply of leisure and shopping services than that needed in developed market economies.

In terms of relations with stakeholders, the transitional context was reflected in the way hotel enterprises were linked to the local operating environment. Foreign-managed hotels resorted to their global resource base and thereby minimized contacts with the local market, whereas local hotels built new business networks partly on the basis of their Soviet-era contacts. In relations with the public sector, Russian-managed hotels applied the template of close personal contacts, whereas foreign-managed hotels adopted their global policy of keeping "wheeling and dealing" to a minimum.

\section{Supplier relations - building networks and relying on own imports}

As the socialist planning system was dismantled, former state hotels had to take over the supply function themselves and build direct supplier relationships. The market for supplies started to develop; although there was still a shortage of quality supplies such as foodstuffs (Taylor 1994). Often, former Soviet enterprises or parts of them continued functioning in a new form. Hence, supplier relationships were often based on old personal contacts. Many suppliers were, however, not able to meet the requirements of a market economy regarding, for example, the quality of their products and delivery times. Hotels coped with this situation by keeping a reserve of alternative suppliers. This gave them security, as sometimes suppliers disappeared overnight or failed to deliver orders on time (Taylor 1994).

Foreign-managed hotels with high quality requirements needed to adapt their sourcing practices to keep up their quality. They relied on imported supplies 
such as foodstuffs, and even imported goods themselves, in the early years of the transition. They also maintained huge inventories of supplies. The reliance on imports was due to two factors. First, local products either did not exist or were of inferior quality, and second, foreign products were not yet available on the market.

\section{Customer relations: Global reservation systems vis-à-vis local partnerships}

The structure of the demand in the St Petersburg hotel market of the early transition had a polarized nature. All foreign-managed hotels of the city were positioned in the 5-star segment and almost exclusively served foreign customers. Soviet hotels represented lower price segments and their clientele mainly consisted of Russian and other former Soviet citizens. Foreign-managed hotels relied mainly on their own worldwide reservation networks, due to both the global nature of the business and to a lack of local demand.

The former state hotels faced a challenge, as the central Soviet tourism organs that had ensured occupancy were dissolved. The main way to cope was to establish internal sales and marketing departments, which contracted with newly emerging private travel agencies and tour operators. However, the majority of tourist firms served outbound tourism, limiting the number of potential sales and marketing partners of hotel enterprises. In addition, there were a number of tourist firms that had a "quick cash and disappear" approach. Finally, on-line reservation systems maintained by hotel chains and consortia were practically nonexistent during the early transition. On the one hand, the majority of the hotels were independent, and on the other hand, they did not have the computer technologies needed to use such systems.

\section{HRM strategies: Money the main motivator}

The transition forced hotels to adapt their HRM function as well. In the former state hotels, the number of staff was cut rather radically and increasing attention was paid to service quality. However, the level of service still lagged behind due to the lack of hospitality traditions. Foreign-managed hotels had large teams of expatriates, used to launch the operations and train the local staff. The Russian staff usually came from outside the industry, as foreign hoteliers did not want to hire staff accustomed to the Soviet type of service but preferred people with higher education and fluency in foreign languages. The motivation to work in the hotel industry was usually the relatively high salaries paid by foreign hotels, rather than a professional interest: "People worked in customer service for money, not because they have a passion for it."

Furthermore, when the Soviet system collapsed, the provision of social benefits was transferred to the responsibility of the employer. Most hotels limited the benefits to statutory ones, such as compulsory medical insurance. Moreover, free meals, uniforms and transportation were often provided, as well as "material" 
(i.e. financial) help when needed. However, some of the hotels continued to provide "Soviet-time" benefits, such as recuperation in sanatoriums and children's camps. Interestingly, some state hotels cut benefits to the bare minimum, whereas some foreign managed hotels (with the city as shareholder) kept up the Soviet-era social infrastructure.

\section{Relations with the public sector: Importance of personal contacts}

The legacy of the Soviet era was most visible in hotels' relations with the public sector. Here, the gap between Russian and foreign-managed hotels was particularly wide. In addition to frequently changing legislation, ill-defined practices of public sector officials in enforcing the regulations were characteristic of the transition period. To be informed about legislative changes, Russian-managed hotels relied on personal contacts in the city administration "It's better to be friends with the tax inspectors, the tax police, everybody. [...] Not for closing their eyes to something, not at all, but to get information in time." Good relations with public sector officials were maintained through "gestures of attention", such as hosting a dinner, or sending flowers or a box of chocolate on the official's birthday.

In addition, inspection visits of various administrative bodies to hotels were frequent. Often, they were used as a means to collect payments that ended up in the official's own pocket. In particular, foreign-managed hotels received attention: "The local administration harassed us practically weekly; we were blamed for ridiculous things, and threatened with arrests and fines. We were often caught, because we don't want to play games..." As a rule, foreignmanaged hotels took a strict standpoint towards corruption. Rather, the importance of acquiring all the necessary information beforehand when making new initiatives was stressed as means to fulfil all requirements and thereby avoid problems.

\section{Post-transition period: The gap narrowing down}

This section illustrates how the institutional context in the St. Petersburg hotel industry evolved during post-transition following the 1998 financial crisis, and the respective changes in structures and practices of hotel enterprises. The main aspects of this period are summarized in Figure 3.

The figure illustrates how the institutional context in the St. Petersburg hotel industry became more established during post-transition, and pressures towards homogenization strengthened somewhat. However, imperfect state regulation still allowed hotel operations in the "grey zone". Moreover, the division between upper-class foreign-managed and lower-class Russian-managed hotels became less strict. Foreign hoteliers started to eye the mid-class segment, and Russianmanaged 5-star hotels began to appear. Instead, the legitimacy of operations 
became the major factor differentiating enterprises in the sector. The next section will illustrate this in more detail.

Figure 3. Post-transition: Narrowing the gap

FIELD-LEVEL INSTITUTIONAL CONTEXT

- Industry regulation still with gaps allowing "grey" business

- Role of professional associations strengthening

- Managerial networking limited to sub-fields

- New generation of hotel industry professionals growing up

- Personnel transfer still infrequent

\begin{tabular}{|c|c|c|c|}
\hline & LEGAL HOTELS & & ILLEGAL HOTELS \\
\hline Structure & $\begin{array}{l}\text { Foreign-managed properties private- } \\
\text { private partnerships } \\
\text { Russian-managed hotels independent } \\
\text { and owner-managed }\end{array}$ & \multirow{8}{*}{ Practices } & $\begin{array}{l}\text { Premises registered as apartments } \\
\text { Services limited to offering "place } \\
\text { to stay in" }\end{array}$ \\
\hline \multirow[t]{7}{*}{ Practices } & $\begin{array}{l}\text { Importance of personal contacts in } \\
\text { public sector diminishing }\end{array}$ & & Bribery common \\
\hline & Long-term supplier contracts & & \multirow{2}{*}{$\begin{array}{l}\text { Low quality of supplies and } \\
\text { equipment }\end{array}$} \\
\hline & Foreign hotels' supply localized & & \\
\hline & $\begin{array}{l}\text { New generation of local managers } \\
\text { growing up }\end{array}$ & & $\begin{array}{l}\text { Personnel unqualified, service } \\
\text { standards not followed }\end{array}$ \\
\hline & $\begin{array}{l}\text { Personnel recruited from profile } \\
\text { institutes and trained in-house }\end{array}$ & & \multirow[t]{2}{*}{$\begin{array}{l}\text { Part of salary "in envelopes " to } \\
\text { avoid social contributions }\end{array}$} \\
\hline & $\begin{array}{l}\text { Minimum social benefits based on } \\
\text { legislation }\end{array}$ & & \\
\hline & $\begin{array}{l}\text { Internet-based reservation networks } \\
\text { and hotel consortia }\end{array}$ & & $\begin{array}{l}\text { Marketing information not based } \\
\text { on the quality of the product }\end{array}$ \\
\hline
\end{tabular}

\section{Institutional environment during post-transition: Stabilization of market conditions}

The 1998 financial crisis was a watershed in Russia, turning the political and economic turmoil of the 1990s into stability and rapid economic growth. President Vladimir Putin's entry into power in 2000 further fostered institutional reforms, and market infrastructure was already functioning better.

The institutional context of the hotel industry and its sources for isomorphism changed as well, as market economy structures became more established and the involvement of the city government in the industry diminished. Coercive isomorphic pressures originating from state regulation were, however, still 
weak. In particular, the emergence of a new type of enterprises, mini-hotels, revealed gaps in the industry legislation, which did not recognize such a concept at all. Moreover, although attempts were made to create a single national rating system, the credibility of hotel certification as a regulative measure continued to be low, "Stars can be bought for money - you apply for 3 stars because your hotel meets the 3-star criteria and they offer you 4 stars if you pay something extra."

In contrast, the role of professional associations as a source of mimetic isomorphic pressures strengthened somewhat, as new types of actors such as mini-hotels founded their own associations. There was, however, still no local industry association that could unite the city's hotel enterprises. Moreover, there were common views among hotel managers that such associations were more marketing instruments for their participants instead of having a real effect on the dissemination of industry practices. Associations were also criticized for being out of touch with reality: "The lecturers in their seminars are university people, who are fascinated with their theories - we should have experienced managers instead."

Moreover, personnel transfer as a vehicle for mimetic isomorphism started to occur more frequently. It took place, however, more between foreign-managed hotels and from Russian-managed to foreign-managed hotels. Russian-managed hotels were still not considered as attractive employers in comparison to foreignmanaged properties. Interestingly, Russian managers still considered personnel transfer as something to be avoided, rather than a fact of life. "Personnel turnover means that either a good hotel did not want to keep a bad specialist, or a bad hotel could not keep a good specialist."

Furthermore, professionalization as a source of normative isomorphism started to gain strength. In particular, the educational profile of managers and employees in the industry started to change towards a more professional direction as the efforts of newly created educational programs and hotels' own training started to bear fruit. However, the local training system was still not developed enough to produce qualified managerial staff to meet the needs of new hotels. Thus, most managers of Russian-managed operations still came from outside the industry. In foreign-managed hotels the training efforts already started to show results, as mid-management positions previously held by expatriates could be filled with young Russians rising through the ranks in the company. In contrast to managers, the staff of Russian-managed hotels already had a predominately industry education, as most hotels recruited from professional institutes.

The second indicator of professionalization, managerial networking, was still not significant. Communication and information exchange between hotel managers in St. Petersburg was mainly limited to unofficial communication taking place between managers of hotels of the same category. Here, the foreign- 
managed hotels still formed a club of their own. There were signs, however, that things were changing in this respect, as Russian managers with little industry experience were more open to share their experiences with others than the "red executives". Moreover, as the supply of hotel services started to grow, hotels had to pay increasing attention to ensuring demand, particularly during the offseason. In addition, the city's diminishing allocation of budget funds to tourism promotion (with the city's 300-year anniversary in 2003 an exception) resulted in hotels joining forces to promote the city as a tourist destination. A joint initiative, "White Days", was developed by the city's 5-star hotels and other tourist industry actors such as museums and theatres to promote the city as a winter destination abroad. The city authorities welcomed the effort to the degree that it evoked a bitter comment from an expatriate manager "After cutting the promotion budget to zero after 2003, the city now wants to piggyback the White Days program."

\section{Organizational practices of hotel enterprises during post-transition}

The strengthening of market economy institutions resulted in a decreasing need for strategic and structural adaptation for hotel enterprises. In terms of structure, hotels returned to their core service domain and private ownership started to prevail. In terms of practices, foreign and local hotels started to converge as the former started to integrate more tightly into the local operating environment. The main change in St. Petersburg hotels' structure during the post-transition concerned ownership, as the city government was replaced with private owners. The city government's relinquishment of hotel ownership in a series of auctions in 2004 and 2005 was the end result of a kind of "one step forward, two steps back" ownership and privatization policy that City Hall had implemented since 1999. The city shares in hotels were mainly acquired by Russian investors.

Private Russian investment into hotel construction picked up as well. Consequently, joint ventures between foreign hoteliers and the city government were replaced with conventional management contracts with Russian construction and real estate companies. Local hotel developers, who often lacked industry experience, began to understand the value of a foreign management company, whose reputation helped in negotiations to obtain financing for the project and whose expertise was valuable during the construction. In contrast, a major part of the city's hotels continued to be ownermanaged, as there were no local management chains yet, and many owners of existing properties were still reluctant to give control to outsiders.

A group of its own was formed by the illegal mini-hotels that operated beyond industry regulation, having been registered as apartments: "You have your own apartment, you pay for it just rent as for an apartment, you don't have a license for alcohol, don't have a cash register, and work entirely gray without paying any taxes." These illegal mini-hotels restricted their services to providing a "bed 
to sleep in", in contrast to legally operating mini-hotels, which often position themselves into the upper price segment and provide extensive tourist services. Interestingly, the existence of the illegal segment became very clear in interviews with legally operating mini-hotels as a reference group they wanted to avoid belonging to. This was supported by secondary data on industry development. Hence, in terms of structure the industry had two competing templates: legal and illegal. The former was based on market-based exchange and a shared normative base, and the latter on ignorance about industry norms and regulation. This division was also visible in hotels' stakeholder relations, as the following sections will illustrate.

\section{Supplier relations: Market conditions stabilize}

As the transition proceeded, the local market for foodstuffs and other consumer supplies developed to the stage where only some luxury items such as specific alcohol brands needed to be imported. Furthermore, tender-based long-term supplier contracts replaced keeping a reserve of suppliers on hold. Finding reliable suppliers became easier, as most one-day businesses had already disappeared as the result of a kind of "natural selection". Regarding investment goods, such as furniture, hotels continued to prefer foreign materials because of quality guarantees. Russian production of goods with special requirements for, e.g., fire safety, such as hotel textiles, was still underdeveloped.

In general, respondents of this study stressed the quality of supplies and equipment. Many of them underlined the importance of, for example, bed linen to meet requirements concerning, e.g., fire safety and hygiene. Illegal minihotels were an exception here, as their disobedience of norms and requirements stretched also to this sector. "In hotels it is not allowed to use textiles that are difficult to wash, that are ill-adapted to chemical cleaning. They have bedspreads filled with foam and with ruffles. Who is washing them, how they will look in the future?”

\section{Customer relations: Joining hotel consortia}

During the post-transition, local hotel marketing consortia started to emerge, and Internet-based reservation systems were increasingly applied by Russianmanaged hotels. This in part contributed to the increase in the number of foreign guests. As during the transition, foreign-managed hotels continued to rely on their global reservation systems, although the local demand for their services picked up as well.

A persisting problem in the city's hotel sector continued to be the high seasonality of demand. During the "white nights" summer season the city were packed with tourists, whereas in winter occupancy rates were low. The situation was made worse by the state institutions, which scheduled high-level political 
and other events to the high season. Here, hotels developed marketing strategies for the winter season, as was previously illustrated.

Legally operating mini-hotels were in a somewhat difficult position regarding their position in the market, as they did not want to associate with the illegal mini-hotels, which often used questionable marketing practices. "They do not correctly advertise themselves, often embellish their services, which does not correspond to reality."

\section{HRM strategies: The importance of right service attitude}

The HRM practices between foreign- and Russian-managed hotels started to converge during the post-transition. A majority of hotel staff were students or young graduates of professional institutes, and the main criteria for hiring personnel was their having the right service attitude. As the educational institutions still failed to equip students with sufficient skills, the need for inhouse training continued. Hotels in the legal segment provided training both inhouse and by resorting to external experts. Illegal hotels, in contrast, put limited emphasis on training personnel in proper ways of working: "The personnel are taken directly from the street, without figuring out how hotel work should be organized, as a matter of fact."

The range of social benefits provided continued to vary from basic benefits defined by the law to more comprehensive social packages. Interestingly, even some of the new Russian and foreign-managed hotels revived some Soviet era traditions, such as the "socialist competition": "At the end of the year we always organize a competition of the best employee of the department, reward the winner with a plaque of honour, a monetary prize, and people are motivated to work better and to compare themselves against others." Finally, operating transparently by paying full taxes and pension fund contributions was also considered a social benefit. The illegally operating hotels broke the norms in this sense as well, as paying "gray" salaries was a part of their tax evasion policy.

\section{Public sector relations: Need for personal contacts diminishing?}

The regulative environment was in general stabilizing, but there was still room for improvement: "Our legislation changes so often that when you read about it, your hair rises: today one, tomorrow another, the day after tomorrow a third." Consequently, the need for personal contacts in public administration to gain information continued.

However, there were also signs that the tradition of having close contact with authorities was gradually disappearing. Instead, it was considered sufficient to operate transparently and fulfil all requirements. Comments, such as "Giving small gifts to civil servants... that has been gone for 10 years." and "It makes no 
sense to patch up a hole with money - the hole will be there anyway." illustrate this.

In addition, corruption was still viewed a problem, in particular related to important decisions such as the allocation of sites for hotel construction. In everyday operations, bribery was primarily associated with illegal hotels:" If I have a hotel that has no chance of being approved by the fire inspection, or sanitary control, I have to pay bribes." Finally, the partnerships with private Russian constructors brought new means for foreign management companies to cope with public sector demands: "Whenever we face a challenge (I don't say a problem) with the public sector, we ask our partner to take care of it. It's up to him how he deals with it, I'm not asking."

Figure 4. Key findings of the study

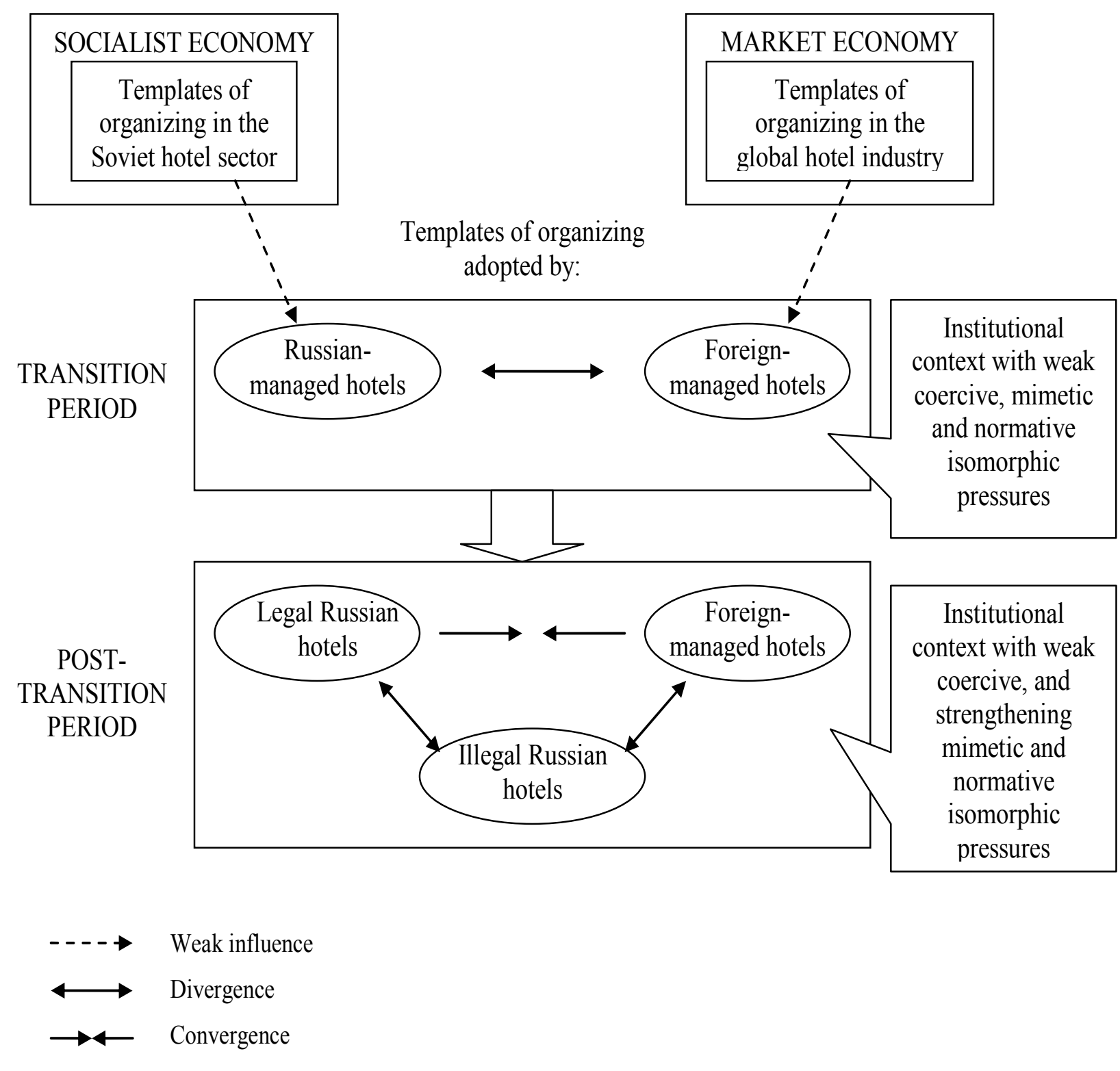




\section{Discussion and conclusion}

This article examined how the institutional contexts and organizational practices of different types of hotel enterprises co-evolved in the St. Petersburg hotel industry as the post-socialist transition in Russia progressed from 1991 to 2005. Figure 4 summarizes the key findings.

The results of the empirical analysis contribute to a better understanding of enterprise adaptation to changing institutional contexts. First, I showed how under macro-level institutional upheaval, the existence of field-level pressures towards homogeneity and their impact on organizational practices are not evident. In particular, during the early years of the transition, when old industry structures are abolished and new ones are under construction, enterprises are practically "self-guided" as the institutional environment does not provide them with "templates of organizing". Here, institutional theory proposes that local incumbents would stick to the templates of the old system, and foreign entrants would apply imported templates. However, my empirical analysis suggests that in the case of the hotel industry, both old and foreign templates needed substantial adaptation during the transition. The key reason was the imperfect market environment, which made the foreign entrants isolate themselves from the local operating context by relying on their global resource base. Russianmanaged enterprises (old Soviet hotels and the few new start-ups) in contrast needed to build local networks.

Moreover, I illustrated that institutional forces, such as state regulation, models for mimicry and professionalization evolve only gradually as the transition proceeds. However, I also showed that the continued lack of coercive pressure from the state results in the emergence of a new category of hotels: illegally operating ones, which ignore the institutional norms that most hotels already share. When mirroring against institutional theory, my contribution in this regard is that the logic explaining diversity in enterprise behaviour changes as the transition proceeds. During the transition, diversity is based on management - foreign versus local. Foreign-managed hotels are able to rely on their global resource base and organizational templates, and consequently behave differently from locally-managed hotels that do not have this opportunity. During the posttransition, however, this gap between "us and them" gradually narrows as the market economy gains a stronger foothold. Instead, the legitimacy of operations becomes the new basis for diversity. This illustrates that the market infrastructure has developed, but the institutional context still has gaps, which provide opportunities for grey business. My research thus concurs with Peng (2003) who proposed that the institutional pressures faced by the different types of enterprises converge as the transition proceeds, which narrows down the gap between their strategic behaviours.

Third, my study shows that although market economy practices have been disseminated rapidly in the St. Petersburg hotel sector, the legacy of state 
socialism is still visible in certain aspects. For example, some new hotel enterprises apply practices of socialist enterprises such as encouraging "socialist competition" between employees, and foreign-managed hotels may maintain extensive social infrastructure. In this sense, my study joins Kosonen (2004) who showed that in transition economies, both local incumbents and foreign entrants are likely to mix old and new thinking. However, the overall conclusion is that the St. Petersburg hotel sector "fundamentally operates in a marketoriented, competitive fashion" (Puffer/McCarthy 2007: 5). My study thereby supports the findings of Puffer/McCarthy (2007) on the prevalence of market capitalism in the Russian consumer sectors.

\section{Limitations of the study and suggestions for further research}

Like all research, this article has its limitations. First, the nature of the study was exploratory and aimed at describing the institutional change at the industry level. This limited the depth to which the strategic choices of individual enterprises were addressed. Further research would hence benefit from a more in-depth investigation of selected case companies on one hand, and from a survey-based examination of selected business practices among a wider population of enterprises on the other.

Second, due to its theoretical underpinnings, this study focused on the role of the institutional environment in the strategic action of enterprises. Therefore, enterprise preferences were addressed only to the extent that they are institutionally derived. However, it is recognized that strategic enterprise action is driven not only by institutional but also competitive pressures from the environment, which shape enterprise preferences. Hence, further analysis would benefit from the combined examination of the relative weights of these pressures. To gain a more comprehensive picture of industry dynamics, qualitative data would need to be combined with quantitative indicators describing industry characteristics.

\section{References}

Bevan, A./Estrin, S./Meyer, K. (2004): Foreign investment location and institutional development in transition economies, in: International Business Review, 13, 43-64.

Brouthers, K.D./Bamossy, G.J. (1997): The role of key stakeholders in international joint venture negotiations: Case studies from Eastern Europe, in: Journal of International Business Studies, 28, 285-308.

Child, J./Markóczy, L. (1993): Host-country managerial behavior and learning in Chinese and Hungarian joint ventures, in: Journal of Management Studies, 30, 611-631.

DiMaggio, P.J./Powell, W.W. (1983): The iron cage revisited: Institutional isomorphism and collective rationality in organizational fields, in: American Sociological Review, 48, 147-60. 
DiMaggio, P.J./Powell, W.W. (1991): Introduction, in: Powell, W.W./DiMaggio, P.J. (eds.): The new institutionalism in organizational analysis. Chicago, IL: University of Chicago Press, 1-38.

Gavrilov, A.I. (1998): Inturist - 1929-1990 gg., in: Turistskie firmy, 15, 210-214. [Inturist from 1929 to 1990, in Russian].

Greenwood, R./Hinings, C.R. (1996): Understanding radical organizational change: Bringing together the old and the new institutionalism, in: Academy of Management Review, $21,4,1022-1054$.

Gudbergsen, L. (1996): The Russian Hospitality Industry -A Market Economy Evolves. A report by Arthur Andersen available at http://www.hotel-online.com/Trends/Andersen /TheRussianHospitalityIndustry_Spring 1996.html.

Hoskisson, R.E./Eden, L./Lau, C.M./Wright, M. (2000): Strategy in emerging economies, in: Academy of Management Journal, 43, 3, 249-267.

Hutchings, K./Michailova, S. (2004): Facilitating knowledge sharing in Russian and Chinese subsidiaries: The role of personal networks and group membership, in: Journal of Knowledge Management, 8, 2, 84-94.

Karhunen, P. (2002): International hotel companies in Russia: The choice of entry mode, in: Journal of East-West Business, 8,3-4, 83-101.

Karpova, G.A. (2003): Kulttuurimatkailun asiantuntijoiden kouluttaminen, in: Muuttuva Matkailu, 4, 54-56. [On educating specialists for cultural tourism, in Finnish].

Kosonen, R. (2004): Adapting to post-communist uncertainties: Foreign investors in Russia must learn to navigate the social and political complexities of business in the region, in: European Business Forum, 18, 36-40.

Kvartal'nov, V.A. (1999): Inostrannyi turizm. Moscow: Finansy i statistika. [Foreign tourism, in Russian].

Langley, A. (1999): Strategies for theorizing from process data, in: Academy of Management Review, 24, 4, 691-710.

Larson, M.S. (1977): The rise of professionalism: A sociological analysis. Berkeley: University of California Press.

Meyer, K.E. (2001): Institutions, transaction costs, and entry mode choice in Eastern Europe, in: Journal of International Business Studies, 32, 2, 357-367.

Meyer, K. E./Estrin, S. (2001): Brownfield Entry in Emerging Markets, in: Journal of International Business Studies, 31, 3, 575-584.

Meyer, K. E./Nguyen, H.V. (2005): Foreign investment strategies and sub-national institutions in emerging markets: Evidence from Vietnam, in: Journal of Management Studies, 42, 1, 63-93.

Meyer, K.E./Peng, M.W. (2005): Probing theoretically into Central and Eastern Europe: Transactions, resources, and institutions, in: Journal of International Business Studies, $36,600-621$.

Michailova, S. (2000): Contrasts in culture: Russian and Western perspectives on organizational change, in: Academy of Management Executive, 14, 4, 99-112. 
Michailova, S./Husted, K. (2003): Knowledge-sharing hostility in Russian firms, in: California Management Review, 45, 3, 59-77.

Newman, K.L. (2000): Organizational transformation during institutional upheaval, in: Academy of Management Review, 25, 3, 602-619.

Peng, M.W. (2000): Controlling the foreign agent: How governments deal with multinationals in a transition economy, in: Management International Review, 40, 2, 141-165.

Peng, M.W. (2003): Institutional transitions and strategic choices, in: Academy of Management Review, 28, 2, 275-296.

Peng, M./Heath, P.S. (1996): The growth of the firm in planned economies in transition: Institutions, organizations, and strategic choice, in: Academy of Management Review, $21,2,492-528$.

Puffer, S./McCarthy, D.J. (2007): Can Russia's state-managed, network capitalism be competitive? Institutional pull versus institutional push, in: Journal of World Business, 42, 1-13.

Puffer, S./McCarthy, D.J./Zhuplev, A.V. (1996): Meeting of the mindsets in a changing Russia, in: Business Horizons, November-December, 52-60.

Ralston, D./Holt, D./Terpstra, R./Yu, K. (1997): The impact of national culture and economic ideology on managerial work values: A study of the United States, Russia, Japan, and China, in: Journal of International Business Studies, 28, 177-207.

Roth, K./Kostova, T. (2003) Organizational coping with institutional upheaval in transition economies, in: Journal of World Business, 38, 314-330.

Salmi, A. (1995): Institutionally changing business networks, Ph.D. Dissertation, Helsinki School of Economics and Business Administration. Helsinki: HSEBA Publications, A106.

Scott, W.R. (1998): Organizations: Rational, Natural and Open Systems. $4^{\text {th }}$ ed. Upper Saddle River, NJ: Prentice Hall.

Taylor, D.W. (1994): Strategic planning, Russian style, in: Cornell Hotel and Restaurant Administration Quarterly, 35, 1, 82-89.

Tolbert, P.S. (1985): Resource dependence and institutional environments: Sources of administrative structure in institutions of higher education, in: Administrative Science Quarterly, 30, 1-13.

Wright, M./Filatotchev, I./Hoskisson, R.E./Peng, M.W. (2005): Guest Editors' Introduction, Strategy Research in Emerging Economies: Challenging the Conventional Wisdom, in: Journal of Management Studies, 42, 1, 1-33. 